\title{
Civic Participation and Demonstrations in Portugal (2011-2012)
}

\author{
Célia Taborda Silva
}

Universidade Lusófona do Porto

\begin{abstract}
In recent years, a little over the world, emerged social protest, from the Arab Spring to the Indignados, resulting from the dissatisfaction of the citizens and fruit of the speed with which the information circulates and is shared. In Portugal, the tendency to protest was in the same direction as in Europe and the world, as demonstrated by the movements of March 12, 2011 (Scratch Generation), and of September 15, 2012 (Screw the Troika). These movements brought together thousands of people in protest against government policies and in defense of a new political, economic and social model. In several cities of the country, the Portuguese, as citizens, intervened in the public sphere and expressed themselves on issues related to them, such as the crisis, unemployment, exploitation, as persons belonging to a community. The novelty was the use of communication technologies and social networks to appear, acquire visibility, then existence, as Hannah Arendt (2005) would say. Through the use of digital communication, they ignored the traditional leaderships to call out the protests and demonstrate on the streets, causing these phenomena not to be geographically or culturally limited nor institutionally framed. The internet has brought tools that foster sharing, facilitate civic participation and collective action. Thus, at the beginning of the twenty-first century, social movements have come to play a key role in the democratic state, through the representation of the claims of different sectors of civil society, but are these manifestations indicative of a new civic consciousness?
\end{abstract}

Keywords: protest, citizenship, civic participation, Portugal

\section{Introduction}

The beginning of the 21 st century has seen numerous public demonstrations take place, both in Portugal and around the world. Media outlets have focused considerable attention on such demonstrations, which has significantly increased their visibility among all sectors of society.

Over the last decade, however, more social movements than ever before have been launched, and there has been a noticeable shift from movements of one class to class movements in which all social categories are represented and which challenge the democratic process itself. The movements of 12th March 2011 ('Scratch Generation') and 15th September 2012 ('To Hell with the Troika') exemplify the discontent felt by many Portuguese citizens. These movements brought many people to the streets to protest against government policies and to call for a new political, economic and social model. Movements such as these claim to not be associated with any particular political party, and they pledge to defend secularism and peace, as well as to fight for a fairer world, as was the case with movements such as the 'Indignados' and 'Occupy Wall Street', which rose to prominence in other countries worldwide. The social movements of the 21 st century exhibit a different configuration to that of previous social movements, which emerged during the 1960s and were known as the new social movements (NMS), in terms of their organisation, dimensions, dissemination, and national and international media impact. All these differences distance contemporary social movements from previous models. Their greatest novelty is arguably their use of communication technologies and social networks to appear, to acquire visibility, and then to acquire existence, as Hannah Arendt (2005) would say. By using the internet, such movements organised and managed to mobilise thousands of people in several cities in the same country or even in different countries. They reached a size that surpassed both regional and national scales and, hence, became planetary movements seeking new forms of democracy (Farro, 2004), as was the case with the 'Arab Spring'.

Social protest and public protest have always existed in Portugal, although they have intensified significantly over the last decade. It is thus important to verify whether this increase in demonstrations in the public sphere in Portugal is related to a 
greater degree of civic awareness amongst Portuguese citizens or if it is merely conjunctural, being the fruit of economic difficulties (e.g. the 2008 global financial crisis) and enhanced technological facilities. To do so, the present study analyses relevant information published by the Portuguese press and applies a theoretical framework derived from the theories of social movements.

\section{The movements}

\subsection{The 'Scratch Generation' movement}

In 2011, Portugal was in the midst of a serious economic crisis, which was part of the global financial crisis that had begun in 2008 in the United States (i.e. the subprime mortgage crisis) and then spread to Europe as a result of economic globalisation. The Portuguese government tried to quell the crisis by means of austerity measures such as tax increases, wage freezes, pension and career advancements, and price increases.

However, despite these austerity measures, the crisis showed no signs of abating. In light of the failure of the government's economic measures, the spectre of foreign aid hovered over the Portuguese. It was in this context of economic insecurity and political mistrust that the so-called 'Scratch Generation' movement, which campaigned against unemployment and precariousness, was born (Baumgarten, 2013). The movement grew from the challenge launched by young people via social networks and it essentially targeted young people. The promoters of the 'Scratch Generation' were themselves young people, graduates and symbols of the generation, given their status as trainees, fellows or unemployed. They felt angry that their generation was experiencing difficulties becoming economically independent of their parents despite their academic training, and they shared their anxieties with other young people via the internet. They decided to send an open letter to civil society explaining the need to address the precarious working conditions in Portugal, where qualifications, skills and experience were not mirrored by salaries and decent contracts, and where they were pejoratively referred to as 'the generation of five hundred euros'. In fact, in their Facebook appeal, they stated, 'We, the unemployed, "five-sevens" and other poorly paid, disguised slaves, subcontractors, contractors, false self-employed, intermittent workers, interns, trainees, student workers, students, mothers, parents and children of Portugal, let us express our discontent' (Scratch Generation Protest Blog, 2011). The protest stemmed from the right of all citizens to demand education and employment, an expression of citizenship that was not subsumed by the right to vote, as one young person commented. It was also an affirmation of the young people's distrust in the political system; therefore, they affirmed that the movement was to be 'a nonpartisan, secular and peaceful protest, that tries to reinforce participatory democracy in the country' (Scratch Generation Protest Blog, 2011). Comments and behaviour such as this corroborate the opinion of researchers that 'the most educated young people are more active, have more civic awareness and make more use of citizenship rights' (Ferreira \& Silva, 2005, p. 146).

The aim of the 'Scratch Generation' movement was, according to the promoters, to contribute to 'triggering a qualitative change in the country' (Scratch Generation Protest Blog, 2011. They wanted to find solutions to Portugal's problems and to then be part of those solutions. Lacking prospects for the future and in a profound state of frustration, they felt the need to unite and to manifest in the public sphere their claims to rights that were being withheld.

The lack of employment experienced by this generation of qualified young people was not merely a conjunctural problem, since, due to the massification of higher education, there had been an exponential increase in the number of students during the 1990s (Abrantes, 2003). In fact, the number of students in higher education in Portugal rose from around 11,000 to 60,500 during that decade (Abrantes, 2003), making it increasingly difficult for graduates to enter the labour market. Of course, at the time the movement was launched, this structural issue was the least of the young people's worries.

Thus, on 12th March 2011, at 3 pm, the squares in the main cities of Portugal were filled with 'Scratch Generation' protesters. Demonstrations were held in Lisbon, Porto, Braga, Coimbra, Viseu, Castelo Branco, Faro, Funchal and Ponta Delgada. The places chosen for the protests were the centres of cities, squares and streets that were historically emblematic.

In Lisbon, the largest demonstration took place on Avenida da Liberdade. Approximately 200,000-500,000 participants (the number varies according to the information source, that is, the police or the organisation itself) protested against the precarious situation in which they lived. Crowds came from all sectors of society, with the number of demonstrators far exceeding the expectations of both the young promoters and the general participants. The demonstration was surprising not just due to the number of participants, but also due to the different age groups that took part (Jornal de Notícias, 2011). 
A few years earlier, this kind of intergenerational union was almost unthinkable in the context of a single protest. In 1994, secondary school students took part in several demonstrations against the global tests that had to be passed in order to enrol in university. As a result, the older generations labelled them the 'scratchy generation'. This pejorative labelling was generalised in the society of the time, which created a generational gap that would eventually undo itself, at least momentarily, during the demonstration of 12th March 2011. On that day, acting together and taking part in the same march, were not only those directly affected by the economic crisis (i.e. young people), but also the parents and grandparents of those who were 'unemployed and precarious', who had to continue to financially support children who should have been able to self-sustain. The complaints of the young were also the complaints of their older relatives, since the professional instability experienced by the young resulted in the economic degradation of previous generations. As mentioned in an article in Visão (2011a, p. 70), one in five young people aged 25-35 was at that time economically dependent on family. In some cases, even at the age of 40 , people reported having no stable salary and so no ability to fund their own house or family (Diário de Notícias, 2011), although many of these people held higher education qualifications. During the last quarter of 2010 , the number of unemployed graduates rose to 68,500 , which was equivalent to $11.2 \%$ of all unemployed people (Loureiro, 2012, p. 337). With so many living in such precarious economic circumstances, reports of individual injustices quickly circulated via social media, eventually being transformed into a collective injustice. This was reflected in the posters people held during the demonstration, which featured slogans such as 'Living Communism - Spreading Anarchism', 'Capitalism is Abominable', 'The Country is Scratchy' and 'Scratchiness is Precariousness'. Several politicians also joined the Lisbon march despite it being a non-partisan movement, as did members of right-wing extremist groups, anarchists and members of the LGBT community (Jornal de Notícias, 2011).

The solemn parades of yesteryear, which progressed at a slow and almost reverent pace, have now given way to demonstrations in which music and dance add a certain colour to the event. Although these manifestations of protest in Portugal had a playful component, the spectacularity they exhibited was only modest when compared to the performances seen during other European anti-globalisation mobilisations, in which masks and disguises alluded to a certain subversion of the carnival theme, which gave the events a high level of visibility in traditional media outlets.

As an article in Visão (2011b) said of the demonstration seen in Lisbon and which also applied to those in other cities:

It is not only a manifestation, but several: the manifestation of precarious workers, the manifestation of university students with no future, the manifestation of the unemployed, the manifestation of pensioners by anticipation, the manifestation of pensioners of 200 euros, the manifestation of the unschooled workers ... (p. 66).

The movement was a collective action driven by individual interests. Each individual spontaneously joined in after reviewing the situation, as, just like the organisers, they felt themselves to be without future prospects. Effectively, they lacked a group goal that would keep them together beyond the circumstances of the moment. As Pinto (2011) notes, they took part in the demonstration:

for a future, for a job, for the end of green receipts, out of curiosity or just to see what it was like, for raising the minimum wage, for the father, for the daughter, dancing, singing, applauding, shouting, or even in silence, no one dared to imagine that the voices and words would merge into one message (p. 34).

In recent years, a number of studies have pointed to the distancing of young people from 'traditional' or 'conventional' politics, such as participation in party voting or a party affiliation, and the growing interest among this population in 'unconventional' politics, such as collaboration in organisations or associations and protest actions (Magalhães \& Sanz Moral, 2008, p. 27). The popularity of the 'Scratch Generation' movement with young people may be a sign of the divergence of the institutional politics of the democratic state from popular politics, that is, a demonstration that young people have both civic and political awareness, although they distrust the methods of representative democratic politics.

\section{2 'To Hell with the Troika - We Want Our Lives'}

Less than a month after the 12th March demonstrations, Portugal's need for foreign aid was confirmed. On 6th April 2011, the prime minister requested foreign intervention for the country. The inability to pay the public debt was compounded by the need to reduce the public deficit as well as the need to obtain funds to inject into publicly owned, technically bankrupt companies. The measures agreed between the Troika (the International Monetary Fund, the European Central Bank and the European Commission) and the Portuguese government necessitated extreme austerity, which prompted many Portuguese citizens to join the movement of 15th September 2012. 
Given the likely impact of austerity measures, the country responded with a new social mobilisation that, like the 'Scratch Generation' movement, was triggered by interactions via social networks. A group of citizens, representatives of Portuguese society (academics, researchers, artists, etc.), not affiliated with any particular political parties, used social networks to call for a protest motivated by the political context. Their manifesto was as follows:

You must do something extraordinary. We must take the streets and squares of the cities and our fields. Putting together the voices, the hands. It is necessary to do anything against submission and resignation, against the bottleneck of ideas, against the death of the collective will. It is necessary to call again the voices, the arms and the legs of all and all who know that in the streets the present and the future are decided. It is necessary to overcome the fear that has been expertly disseminated and, once and for all, to realize that we have almost nothing to lose and that the day will come already we have lost everything because we were silent and we gave up alone (queselixeatroikablogspot.pt).

The manifesto called for action against the austerity measures imposed by the Troika, which were popularly considered to represent a plundering of the country's resources. In fact, the austerity measures were perceived to have been driving Portuguese citizens and the country itself towards poverty and degradation for more than a year, without leading to any appreciable improvements. The manifesto continues:

... anyone who resigns to govern under the troika memorandum delivers the fundamental instruments for the management of the country in the hands of speculators and technocrats, applying an economic model that is based on the law of the jungle, the strongest, despising our interests as a society, our living conditions, our dignity (queselixeatroikablogspot.pt).

And it ends with a clear call to collective action, 'They divided us to oppress us. Let's get together to get free!'.

Although the movement initially appeared to be spontaneous, that was actually not the case. Since July 2012 , activists belonging to the Inflexible Precarious group and other militant organisations had been preparing for a large demonstration. The prime minister would inadvertently give them a nickname when he uttered the phrase 'to hell the elections ' in a speech. This phrase was reused to create the slogan 'To Hell with the Troika - We Want Our Lives', which would later be used in opposition to the government (Babo \& Silva, 2015). It was assumed that the activists were backed by left-wing political parties, but that was also not the case. The activists' goal was to spread word of a non-partisan demonstration intended to bring together various political sensitivities. Indeed, it was the notion of non-partisanship that attracted people to the movement.

This second movement actually proved to be more effective than the previous one, in terms of both the number of demonstrators and the number of cities in which demonstrations took place. In Lisbon, around 500,000 people gathered in the most representative squares and streets.

Although the 'To Hell with the Troika' movement was formed thanks to the development and diffusion of modern technologies, the activists still felt the need to make use of traditional spaces of protest, just as previous movements had done (Tilly, 2004). The historical places chosen to host the demonstrations, in addition to being indicative of the idiosyncrasy of a people, provided for a kind of encounter between the past and the future. The streets chosen for the demonstrations functioned as symbols of the communal union of yesteryear. Solidarity has always been a fundamental element of collective action, and it has traditionally been constituted in the daily sharing practiced within a community or a workplace. In protest movements such as the 'Scratch Generation' and 'To Hell with the Troika', the solidarity was virtual, as it was based on the anonymity of the mobilisation. Hence, the space of action attained a greater relevance for the purposes of identification. The individualisation of the manifestations is a characteristic of these modern movements, which stands in contrast to the key characteristic of previous movements. The 'l' and the 'other' were easily recognised as the 'we' during the preceding two centuries, having been forged in the struggles shared in the factory, in the daily experiences of the living space, or in the organisation of militancy. Yet, in these two modern Portuguese mobilisations, the individualisation, the anonymity and the impersonality of the relations between the participants stood out.

The 'repertoire' (Tilly, 2004) of the movement would also be reflected in later mobilisations. In 2013, the 'To Hell with the Troika' movement organised two more major demonstrations, one on 2nd March under the slogan 'To Hell with the Troika - The People Rule the Most' and another on 13th October with the motto 'To Hell with the Troika - There Are No Dead Ends'. During these demonstrations, the repertoire of social criticisms increased, as did the demands for solutions to economic and social problems. Although they continued to assert that they were movements of ordinary people seeking to actively participate in the solving of similar problems, a whole political discourse can be found in the groups' manifestoes, 
while representatives of political parties took part in the protests and commented on them in the media. The slogans used were intended to rekindle the spirit of the Carnation Revolution of 1974, which resulted in the ending of 40 years of dictatorship. As such, the activists wrote phrases such as 'Soft Customs Have Limits', 'Loose the Grândola that is in You' and 'The People Demand More' on their posters. In the speeches given during the demonstrations, in another allusion to the revolution of 1974, there were constant reminders that the freedoms and rights acquired by the people cannot be reversed in the name of a supranational authority that oppressed and failed to represent the citizens. It was to the streets that the Portuguese returned to relate to one another, and it was on the streets that the freedom of participation in the discussion of public affairs was reaffirmed. The political situation of Portugal in 2012 was completely opposite to that of 1974. The Carnation Revolution overthrew a dictator and instituted a democratic state, but the allusion to the past was intentionally symbolic. The political and social movement that occurred in 1974 had national and international impacts. For some authors, such as Boaventura Sousa Santos (1984), the movement was the 'broadest and deepest in postwar history' (p. 18) due to both its size and its significance. The people took to the streets in support of the military coup. After 40 years of dictatorship, Portuguese citizens finally freed themselves from fear and oppression and demanded democracy. In 2012, the Portuguese people recalled the movement through which they conquered their fear and demanded democracy, and it was in the name of democracy that they returned to the streets. Those who took part in the demonstrations did not feel represented by their leaders and they saw the 'submission' to the Troika's plan as an example of authoritarianism that evoked the situation of the past. Manuel Villaverde Cabral (2004) verified that a kind of administrative despotism maintained the historical distance between the elites of power and the population, with the role of the state oscillating between predator and protector. This finding was even more noticeable in 2012, given the crisis situation.

For António Barreto (2004), democracy is based, among other things, on the consensus of citizens regarding the formation and exercise of political power. Certainly, the 2012 movements in Portugal sharply challenged the way in which the country's political affairs were being conducted.

\section{Discussion}

Are the above-mentioned movements a demonstration of citizenship and a new form of democratic participation?

According to the classic conception of citizenship, there is a direct link between being a citizen and engaging in political participation. As Aristotle, in his work Politics, stated, 'we say that they are citizens who can exercise such public functions' (ed.1988, p. 1275-1276). In this way, for philosophers of the classical age, the main characteristic necessary to be considered a citizen was participation in the decisions of the political life of the polis, rather than simply the fact of residing in the territory.

However, this concept gradually faded away throughout history, until it resurfaced with the growth of liberalism. It was through the liberal revolutions and the rise of the bourgeoisie in the 19th century that a new relationship was established between citizens and political power, and it was through the growth of democracies that the conception of citizenship, as associated with civic and political rights, became solidified. The first sociological theory of citizenship was offered by Thomas Marshall, who spoke of three types of citizenship rights, namely civil, political and social rights.

In Portugal, full citizenship incorporating all three types of rights, including the political right associated with unrestricted universal suffrage, was only available after 1974, when the Carnation Revolution ended forty years of dictatorship. In fact, the first Portuguese Constitution (1822) had stated that 'all the Portuguese are citizens' (Ramos, 2004), although this idea only covered civil rights, since only a minority then enjoyed political rights and social rights were not yet being discussed. The citizen, as a 'holder of a part of political sovereignty' (Schnapper, 2000, p. 10), only truly came into existence following the establishment of democracy in the country.

After Portugal joined the European Union, the government committed to providing citizenship education, which led to young people becoming more civically, socially and politically aware and, therefore, to them exhibiting a tendency to be more politically active. At the same time, the technological revolution democratised access to information, thereby facilitating the exercise of citizenship and civic participation, which resulted in the organisation of inorganic demonstrations. Effectively, the mobilisation for the discussed demonstrations was achieved through social networks by young people and adults adept in internet activism, although it was not the fact of the connection that triggered the demonstrations on the streets, but rather the feeling that the rights of citizenship were being suppressed, particularly social rights. Accornero and Pinto (2014) showed, based on Tarow's (1998) theory, that these protests formed part of 'cycle of protests against austerity' (p. 398). 
Tarow (1998, p. 42) attributed certain characteristics to a cycle of protest, including the mobilisation of new actors, innovation in terms of repertoires and the elaboration of new cognitive, cultural and ideological structures, which was verified in the present work. The available statistical data reveal that the number of demonstrators increased significantly between 2008 and 2012 in countries severely affected by the global financial crisis, such as Spain, Ireland and Portugal (Accornero \& Pinto, 2014). This shows that the situation itself boosted the number of demonstrations; however, people only took to the streets because they were aware of their political and social rights. These 'spontaneous' manifestations reveal a certain 'democratic disaffection', as identified by Magalhães (2005). Although there was social support for democracy, there was also a distancing of citizens from political institutions, which resulted in low levels of political, conventional or other participation (Magalhães, 2005, p. 988).

Nevertheless, it is apparent that these movements reveal civic awareness, while participation in street protests demonstrates democratic dynamism and citizenship.

\section{Final reflection}

The protest movements that have occurred in Portugal in recent years, despite the novelty with which they emerged, represent an aspect of the historical contestation that has occurred in the country since the 19th century (Cerezales, 2011; Silva, 2007). The fact that they appeared in a somewhat different form, presenting themselves as nonpartisan, horizontal and without leaders, gave them prominence and visibility, although it did not dethrone or cause to disappear the institutional actors, who continued to be the most demanding sector during the period of crisis (Accornero \& Pinto, 2015, p. 406). Social movements emerging from the democratic space claim to have emerged as new forms of political and social struggle, which does not mean that they have been established as political actors and/or representatives of civil society claims, although their actions may have political consequences and social benefits.

These movements of citizens did not achieve much more than to denounce and claim, especially in the case of the mobilisation of the 'Scratch Generation'. According to Maria da Glória Gohn (2014), in these kinds of protests, 'collectives that draw inspiration from various sources, depending on the group to which they belong, do not have ideological or even utopian hegemony, motivating them a feeling of discontent, disenchantment and indignation against economic and political conjuncture' (p. 13). Thus, such movements actually turn out to be very heterogeneous in terms of their forms and resources, organisations, strategies and ideals, and they are often too dispersed to manifest a highly focused objective and to constitute a centre of counterpower (Cefai, 2005, p. 135). Hence, they only have a sporadic mobilisation capacity, except when they are integrated into institutional bodies such as political parties or trade unions.

The speed with which the above-mentioned movements arose and spread across the social networks gave them breadth and dimension, but their discursive content refers to a very concrete national reality (the austerity of the moment) and their focus was more local than global.

The context of the economic crisis and the political difficulties associated with managing it created an ideal context for the emergence of a new social phenomenon, but as the crisis situation dissipated, the inorganic mobilisations disappeared. During the years that witnessed the greatest crisis (2011-2013), the rights of social citizenship were threatened, and the young people of the 'Scratch Generation' as well as the civil servants and retirees experienced a decline in their quality of life when compared to that of previous generations, which motivated them to participate in the demonstrations. At the same time, the majority of citizens who took part in the demonstrations shared a past characterised by active citizenship.

\section{References}

[1] Accornero, G., \& Pinto, P. R. (2014). "Brandos costumes?"Protesto e mobilização em Portugal

[2] sob a austeridade, 2010-2013. Estudos Ibero-Americanos, Porto Alegre, v. 41, n. 2, 393-421.

[3] Arrighi, G., Hopkins, T. K., \& Wallerstein, I. (1989). Antisystemic movements. London: Verso.

[4] Baumgarten, B. (2013). Geração à Rasca and beyond. Mobilizations in Portugal after 12 March 2011. Current Sociology, $61(4), 457-473$.

[5] Abrantes, P. (2003). Identidades juvenis e dinâmicas de escolaridade. Sociologia - Problemas e Práticas, 41, 93-115.

[6] Arendt, H. (2005). A Condição Humana. Rio de Janeiro: Forense.

[7] Aristóteles. Política. Trad. de Márcio da Gama Kury. $2^{a}$ ed.1988. Brasília: Universidade de Brasília.

[8] Azevedo, M.C. (2009). Experiências de participação dos jovens: Um estudo psicológico. Tese de Doutoramento em Psicologia. FPCEUP,Universidade do Porto, Porto. 
[9] Babo, I.,\& Silva, C.T (2015). Public Sphere and collective Action. The Portuguese Movement of the "15th September". Mediterranean Journal of Social Sciences. Vol.6, $n^{0} 6$., S5, 425-435.

[10] Barreto, A. (2004). A participação e a evolução da sociedade portuguesa. Tempo de Incerteza. Lisboa: Relógio d'Água, 301325.

[11] Costa Pinto, A.; Almeida, P. T. (2001). Libéralisme, démocratie et émergence de la société civile au Portugal. In Daniel Cefai (org.). Cultures politiques. Paris: PUF, pp.503-521.

[12] Costa Pinto, A.; Magalhães, P.; Sousa, L.; Gorbunova, E. (2012). A qualidade da democracia em Portugal. A perspectiva dos cidadãos. Workshop The Quality of Democracyi $n$ Hard Times, ICS-UL, Lisboa.

[13] Cabral, M. V. (2004). Confiança, mobilização e representação política em Portugal, in M. Costa Lobo, Pedro Magalhães e André Freire (eds.), Portugal a Votos - as eleições legislativas de 2002 (pp. 301-331). Lisboa: Imprensa de Ciências Sociais.

[14] Cefai, D. (2005) - Os novos movimentos em França. Revista Crítica de Ciências Sociais, 72, Outubro, 129-160.

[15] Cohen, J. (1989). Deliberation and Democratic Legitimacy, in A. Hamlin e P. Pettit, (eds), The Good Polity. Normative Analysis of the State. Oxford, B. Blackwell, pp.17-34.

[16] Farro, A. (2004). Actors, conflits and the globalisation movement. Current Sociology, vol.52. Londres: Sage.

[17] Ferreira, P.M. \& Silva, P.A. (2005). O Associativismo Juvenil e a Cidadania Política. Lisboa: Instituto de Ciências Sociais da Universidade de Lisboa.

[18] Gohn, M. G. (2014). Manifestações de Junho de 2013 no Brasil e praças dos Indignados no Mundo. Pétropolis: Vozes.

[19] Lévy, P. (2006). Ciberdemocracia. Lisboa: Instituto Piaget.

[20] Loureiro, L. (2011). O Ecrã de Identificação. Tese de Doutoramento em Ciências da Comunicação. Especialidade em Sociologia da Comunicação e da Informação. Universidade do Minho, Braga.

[21] Magalhães, P. \& Sanz Moral, J. (2008). Os jovens e a política. Lisboa: Centro de Sondagens e Estudos de Opinião da Universidade Católica Portuguesa.

[22] Magalhães, P. (2008). Redes sociais e participação eleitoral em Portugal. Análise Social, XLIII: (3. $\left.{ }^{0}\right), 473-504$.

[23] Magalhães, P.(2005). Disaffected Democrats: Political Attitudes and Political Action in Portugal. West European Politics, v. 28, n. 5, 973-991.

[24] Marshall, T. H. (1950; 1992), Citizenship and Social Class, Londres, Pluto Press.

[25] Menezes, I. (2007). A evolução da cidadania em Portugal. Actas do $3^{\circ}$ Encontro de Investigação e Formação: Educação para a Cidadania e Culturas de Formação, 17-34.

[26] Palacios Cerezales, D. (2011). Portugal à coronhada. Protesto popular e ordem pública nos séculos XIX e XX. Lisboa: Tinta da China.

[27] Pinto, M. \& Sousa, H. (2011), Foreword, in M. Pinto e H. Sousa (eds.),Communication and Citizenship - Rethinking crisis and change, Coimbra: Grácio Editor.

[28] Ramos, R. (2004). Para uma história política da cidadania em Portugal. Análise Social, vol. XXXIX (172), 547-569.

[29] Silva, C. T. (2007). Movimentos sociais no Douro no período de implantação do liberalismo (1834-1855). Porto: Gehvid.

[30] Silva, C.T (2014). Social Movements in Contemporary Portugal. European Journal of Social Sciences Education and Research (EJSER). Vol.1, n². Rottenburg: European Center for Science Education and Research, 36-43.

[31] Schnapper, D. (2000). Qu'est-ce que la citoyenneté?. Paris: Gallimard.

[32] Svampa, M. (2008). Cambio de Época: movimientos sociales y poder político. Buenos Aires, Siglo Veintiuno Editores.

[33] Tarrow, S. (1998). Power in Movement: Social Movements and Contentious Politics,Cambridge, Cambridge University Press. Magazines

[34] Tilly, C. (2004), Social Movements: 1768 - 2004. London: Paradigm Publishers.

[1] Jornal de Notícias, ano 2011-2012

[2] Diário de Notícias, ano 2011-2012

[3] Revista Visão, ano 2011 